\title{
$\begin{array}{lllllllll}\text { I } & \mathrm{N} & \mathrm{S} & \mathrm{T} & \mathrm{I} & \mathrm{T} & \mathrm{U} & \mathrm{T} & \mathrm{E}\end{array}$
}

\section{Is New Hampshire's Climate Warming?}

\author{
LAWRENCEC. HAMILTON, BARRY D. KEIM, AND CAMERON P. WAKE
}

\section{Introduction}

In April 2010, the Granite State Poll asked a representative sample of 512 New Hampshire residents what they personally believe about climate change or global warming. ${ }^{1}$ Is it happening now, caused mainly by human activities? Is it happening now, but caused mainly by natural forces? Or is it not happening now? The upper graph in Figure 1 shows results from this poll. Almost 90 percent believed that climate change is happening now, whether natural or human caused. $^{2}$ A separate poll taken in June 2010, for the Community and Environment in Rural America (CERA) project, asked the same question of 1,852 residents in three northern counties of New Hampshire, Maine, and Vermont. The CERA poll found similar results, shown at bottom in Figure 1: 86 percent believed that climate change is happening now. ${ }^{3}$

FIGURE 1. WHAT DO YOU PERSONALLY BELIEVE ABOUT CLIMATE CHANGE?

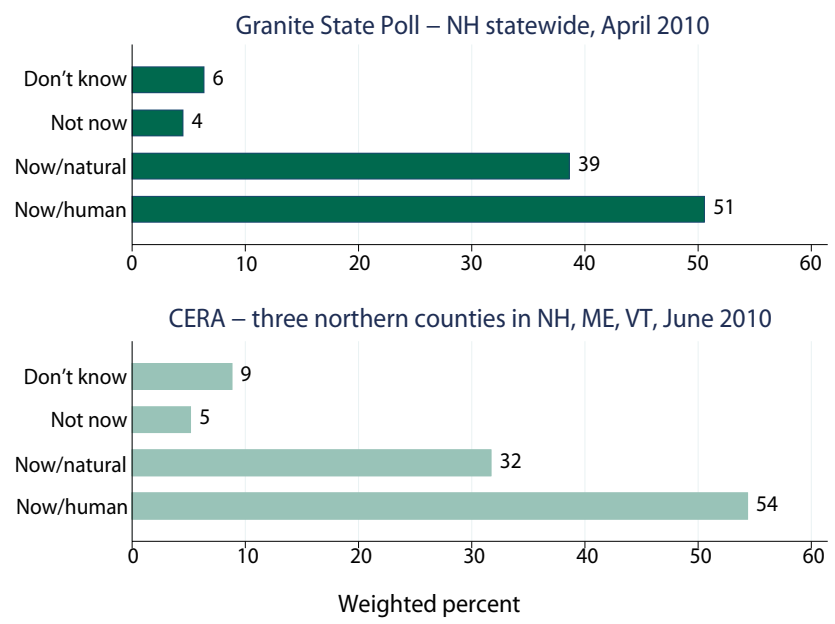

Note: Margins of error are plus or minus 4.5 percent for the Granite State Poll and 2.5 percent for CERA.

\section{Key Findings}

Recent surveys find that most New Hampshire residents believe the climate is changing, whether due to natural or human causes (Figure 1). In this brief, we look at some objective indicators to see whether New Hampshire's climate really has changed and how local trends compare with global patterns. It turns out that New Hampshire seasons, and winters in particular, have been warming at faster-than-global rates. The following are some examples:

- Annual temperatures at First Connecticut Lake, a rural site in far northern New Hampshire, warmed an average of .34 degrees Fahrenheit per decade, from 1895 to 1969, and about 54 degrees Fahrenheit per decade (faster than the global rate) since 1970.

- Winter temperatures in both northern and southern New Hampshire are warming even more steeply, especially through the past forty years.

- Using "temperature anomalies," instead of simple temperatures, helps to make comparisons of trends across places with seemingly much different climates, such as Durham and Mount Washington.

- Ice-out dates on New Hampshire's large lakes provide other indicators of winter warming, which follow patterns similar to those measured for temperature.

- Snowfall responds to temperature change in more complicated ways and often with inconsistent trends.

- Sea level in northern New England, as globally, is now rising at an accelerating rate.

These shifts in New Hampshire's climate, if they continue into the future, will have broad implications for our ecosystems, infrastructure, and economy. 
New England's recent experiences with floods (2005-2007, $2010)$ and relatively warm winters $(2002,2006,2010)$ probably influenced public opinion. Spring arrived early in 2010 .

Of course, there have always been unusually cold or warm seasons, but is something different happening now, compared with earlier decades? Is New Hampshire's climate really changing, as most people seem to believe? In this brief we look back on a century of records from different seasons and different parts of the state. The aim is not to conduct another detailed climate study but to provide some long-term perspective on recent trends. ${ }^{4}$

\section{New Hampshire and Global Climate}

Each month NASA scientists calculate an index of global temperature based partly on historical records from weather stations around the world, such as those maintained by the United States Historical Climatology Network (USHCN). ${ }^{5}$ Five New Hampshire stations-Bethlehem, Durham, Hanover, Keene, and First Connecticut Lake-contribute to USHCN. The upper curve in Figure 2 shows annual temperatures from the most isolated of these stations, First Connecticut Lake, located near the Canadian border in northern New Hampshire. ${ }^{6}$ The lower curve shows global temperature anomalies calculated by NASA, taking into account the five New Hampshire stations along with thousands of others. ${ }^{7}$

Figure 2. Annual temperatures at First Connecticut LAKE IN NORTHERN NEW HAMPSHIRE, COMPARED WITH GLOBAL TEMPERATURE ANOMALIES

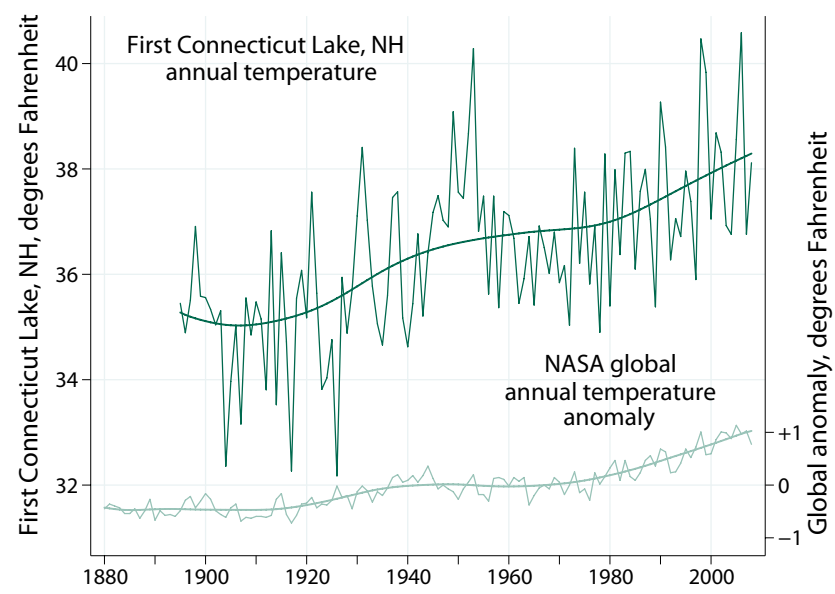

Note: Vertical (degree) scales are the same, although the two series have different "0" points. Smoothed curves summarize patterns underlying the jagged year-to-year variations.
From 1895 until 1970, annual temperatures at First Connecticut Lake rose at an average rate of .34 degrees Fahrenheit per decade, although most of the actual rise occurred in just two decades, 1920 through 1940. The three decades from 1940 to 1970 saw a slight cooling. After 1970, a more sustained period of warming began, at .54 degrees Fahrenheit per decade, well above the global rate (.30 degrees Fahrenheit per decade since 1970). Wide year-to-year variations in temperatures from the single New Hampshire station contrast with relatively small year-to-year variation in global temperatures averaged across thousands of places. The New Hampshire station matches a global pattern, however, of warming between 1920 and 1940, followed by a mid-century cooling, and then sustained warming since $1970 .^{8}$

This general pattern of warming, slight cooling, and then steeper warming since 1970 has been observed in both southern and northern New Hampshire and in all four seasons. It has been most pronounced in the wintertime-about .20 to .35 degrees Fahrenheit per decade between 1900 and 1969, as graphed in Figure 3. ${ }^{9}$ From 1970 to 2009, the average rate of winter warming steepened considerably to 1.06 degrees Fahrenheit per decade in northern New Hampshire and .88 degrees Fahrenheit per decade in the south.

Southern winters are warmer, but the two regions generally move together. That is, a relatively cold winter for the south tends to be relatively cold for the north as well. Such patterns of parallel movement, despite different average temperatures, provide scientists with a way to see global climate change.

Figure 3. Winter (December to February)

TEMPERATURES AVERAGED FOR STATIONS IN SOUTHERN AND NORTHERN New HAMPshire

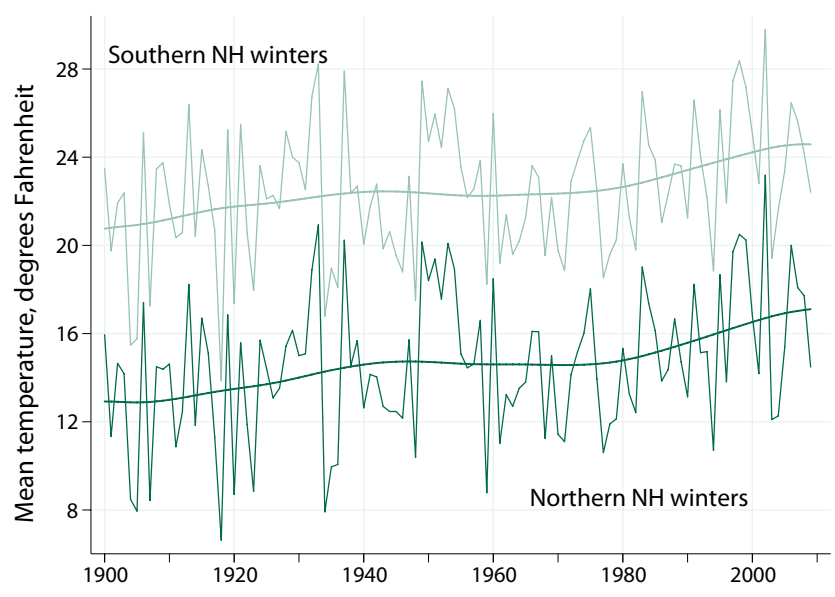




\section{What Are Temperature Anomalies?}

Temperature changes over time are not always measured by changes in averages but also by changes in temperature anomalies. Weather stations record local temperatures in degrees Fahrenheit or Celsius. To describe larger regions or the whole world, climatologists re-express these as "temperature anomalies." A temperature anomaly equals the difference between measured temperature and a baseline temperature, typically defined as the mean for some historical period. For example, the global temperature anomalies graphed in the lower curve of Figure 2 range from -0.73 to +1.13 degrees Fahrenheit, relative to the mean for 1951 to 1980 (baseline years chosen by NASA climatologists). Positive anomalies occur in years warmer than the 1951 to 1980 baseline, and negative anomalies occur in colder years. Trends in temperature anomalies reveal patterns of change. Thus, rates of changes, like the slopes of curves shown in Figures 2 and 3 , will be identical even if we choose a warmer or cooler baseline period.

Estimates of global temperature anomalies, such as the lower curve in Figure 2, are derived from local temperature anomalies, which in turn use data from weather stations around the world. For example, First Connecticut Lake reported a 2008 mean annual temperature of 38.3 degrees Fahrenheit. The average temperature from that station from 1951 to 1980 was slightly cooler, at 36.7 degrees Fahrenheit. So the annual temperature anomaly for 2008 is 38.3-36.7 = 1.6 degrees Fahrenheit, indicating that 2008 was 1.6 degrees Fahrenheit warmer than the baseline period average. Monthly or daily anomalies can be defined in a similar fashion.

Temperature anomalies help us make reasonable guesses about conditions beyond the immediate vicinity of a weather station. For example, temperatures at higher elevations in New Hampshire's mountains tend to be cooler than those at lower elevations. Although a low elevation or coastal weather station's actual temperature would be a poor guess for the mountaintops, its temperature anomaly might provide a surprisingly good guess. To illustrate this point, Figure 4 graphs anomalies from two far-apart stations: Durham, just 80 feet above sea level in southeastern New Hampshire; and the summit of Mount Washington, 6,288 feet above sea level and 100 miles to Durham's north. Mount Washington is famously cold. Although temperatures in these two places are worlds apart, their temperature anomalies more often than not move together.

Using additional weather stations or ones closer to the mountain, we could make even better guesses about anomalies on Mount Washington. Climatologists apply this principle in a more sophisticated way to estimate temperature anomalies of areas between weather stations, checking their estimates against satellite or other available data.

\section{Ice and Snow}

Although the temperature trends shown in Figures 2-4 are real, their magnitude is too small for most of us to notice, compared with large day-to-day variations in weather. When average temperatures move, however, some more visible things change as well. For example, in a warming climate, very warm seasons become more common, and very cold ones become less common. In Figures 2-4, you can see both high and low extremes shifting up or down with the averages. Another result of warming is that winters become shorter, affecting forests, wildlife, farms and gardens, winter sports, and many aspects of everyday life. A rising fraction of winter precipitation falls as rain rather than snow. ${ }^{10}$
If we did not know about the temperature trends seen in Figure 3, historical ice-out dates for New Hampshire's big lakes could tell a similar tale of winter warming (Figure 5). Ice-out dates have been recorded for Lake Sunapee since 1869 and for Lake Winnipesaukee since $1887 .{ }^{11}$ These dates mirror the larger climate trends shown by temperatures: early-twentieth-century warming, followed by a slight cooling in mid-century, and then steeper warming since about 1970. The ice-out date for Lake Winnipesaukee in 2010, March 24, was the earliest ever recorded. Lake Sunappee's 2010 ice-out (April 4) was only the fifth earliest, but the downward trend there has been equally clear. ${ }^{12}$ 
Figure 5. ICe-out dates on LaKes Sunapee AND WINNIPESAUKEE

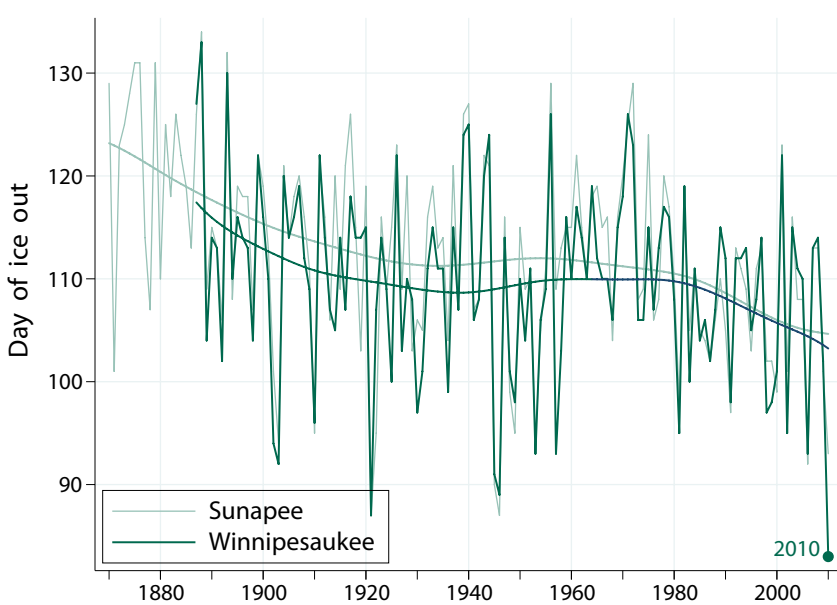

Although it might seem logical that warmer temperatures should mean less snow, the actual response is more complicated. At temperatures far below freezing, air holds less moisture and substantial snowfall becomes less likely than it is when air is closer to, but still below, the freezing point. Consequently, it is possible for some cold places (such as Antarctica, or higher elevations in New Hampshire) to experience more snowfall despite warming temperatures. That pattern reverses when it warms above freezing, of course. New England winter storms often arrive with a moving rain/snow line, and the path of this line can determine whether nearby areas get rain, snow, or an unpleasant mixture of both.

Figure 6. Winter SEAson SNOWfall at Durham and First Connecticut Lake

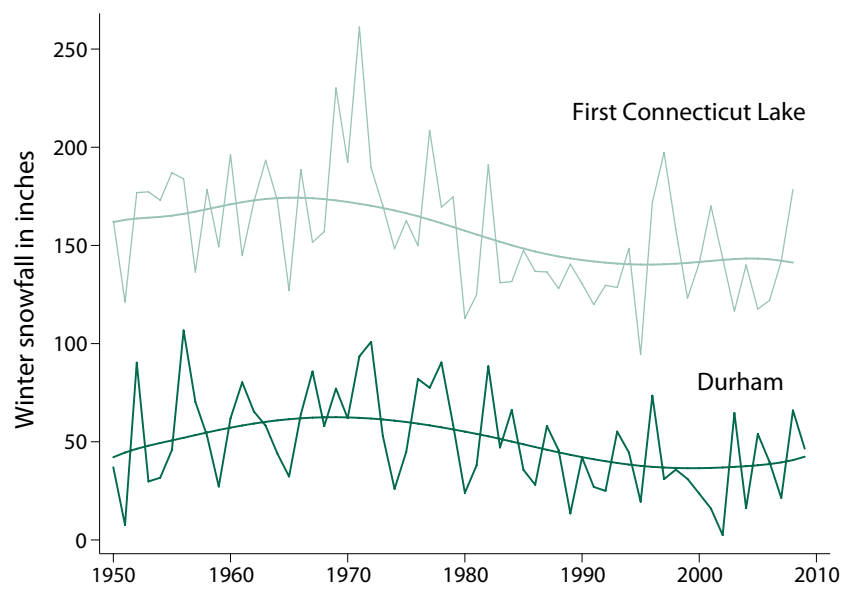

As a result of these complications, and also the difficulties of finding consistent measurements, snowfall trends have been less clear-cut than temperature. Figure 6 shows the up and then down patterns of annual snowfall recorded at Durham and First Connecticut Lake (winters of 1949-1950 to 2008-2009). Snowfall at these stations has declined about one inch per year since 1970 . The similar rates are interesting because snowfall events for these two locations have different climate influences. Coastal conditions particularly affect Durham, while continental storm tracks have more influence at First Connecticut Lake. Weather stations at Bethlehem, Keene, and Hanover, however, recorded no significant snowfall trends over this period.

\section{Sea Level}

Storm erosion and coastal flooding particularly worry towns along New Hampshire's brief seacoast. These problems will increase if sea levels rise. A study for the Office of State Planning noted that a two-foot rise in sea level, which the Intergovernmental Panel on Climate Change (IPCC) has estimated could arrive before the end of this century, would make the flooding from ten-year storms (storms expected to arrive, on average, about every ten years) greater than that of last century's 100 -year storms. ${ }^{13}$ Melting glaciers and the expansion of warming seawater have been raising sea levels worldwide. Figure 7 shows sea level recorded at Portland, Maine, together with global sea level anomalies that follow nearly the same slope. ${ }^{14}$

Figure 7. Monthly sea level at Portland, Maine, COMPARED WITH THE YEARLY GLOBAL TREND

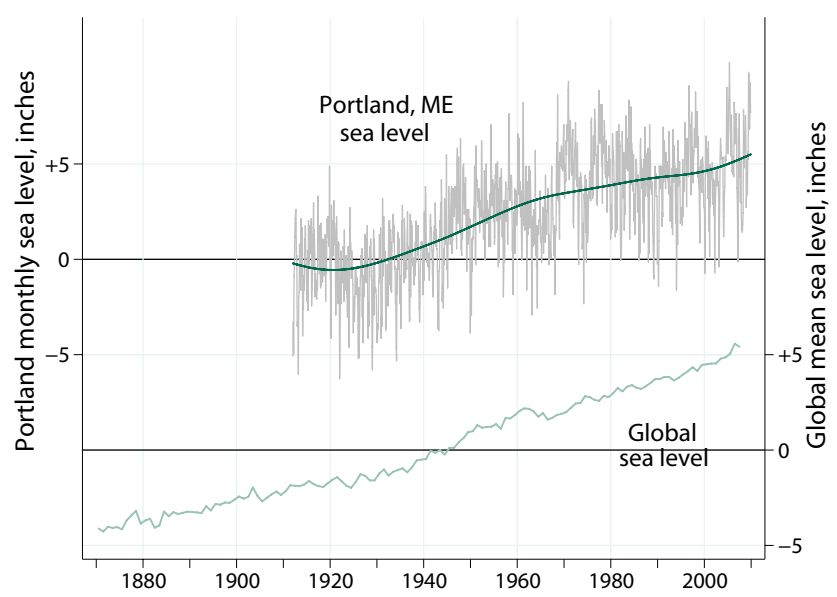

Note: Both curves in this graph are drawn with the same vertical scale with different "0" points. 
Figure 7 shows New England and global sea levels rising at a relatively slow rate through the twentieth century (around eight inches per century). In the first decade of the twentyfirst century, however, the rates of ice loss from Greenland and Antarctica increased, and sea level rose more steeply. The IPCC sea level projections made in 2007 now appear too conservative. Twenty-first century increases on the order of 2.5 to 6 feet appear possible, with correspondingly greater storm flooding. ${ }^{15}$

Oceanographers employ anomalies to estimate global sea level change from tide-gauge records around the world, similar to what climatologists do to estimate global temperature change from weather station data. Error checking and conversion to standard revised local reference (RLR) data occur as raw individual tide-gauge reports from hundreds of places, such as Portland, Maine, are collected by a global databank called the Permanent Service for Mean Sea Level, in England. Further adjustments for geologically rising or subsiding coastlines and calibration with satellite data are part of the careful process for combining tide-gauge based data into estimates of changes in global sea level. Tide gauge or satellite-derived sea level measurements thus provide further indicators, independent of weather stations, showing signs that the world is warming.

\section{New Hampshire's Future Climate}

New Hampshire temperature trends have been similar to or steeper than trends seen for the globe as a whole. They are consistent with results from climate models, which have shown that natural forces alone (such as the effects of volcanoes, solar variation, or climate oscillations like El Niño) cannot explain recent global changes in climate. ${ }^{16} \mathrm{~A}$ large body of scientific evidence shows that climate change has been influenced by human activities, including deforestation, land use or urbanization, and the 26 billion tons of carbon dioxide we are adding to the atmosphere each year. The recent warming trend equivalent to about 5.4 degrees Fahrenheit per century observed at First Connecticut Lake (Figure 2) is already approaching twenty-first-century forecasts of six to fourteen degrees Fahrenheit for the northeastern United States. ${ }^{17}$

Climate change has local effects that include not just warming but also shifts in precipitation, seasons, winds, and storms. In addition to already-observed changes in seasonal warming, spring stream flow, snow depth, growing seasons, and bloom dates, we have future projections of shifts, including less snow cover, more frequent droughts, and longer low-steam flow periods in summertime. ${ }^{18}$

Impacts on sea level are among the most obvious local consequences of a warming climate. The 2001 New England Regional Assessment and 2007 Northeast Climate Impacts Assessment point out others. ${ }^{19}$ A 6 degrees Fahrenheit rise in average annual temperature would give Boston the climate of Atlanta. New Hampshire forests have adapted over centuries and millennia to their northern climate but would struggle to adapt now to rapid climate change. Health of forests, animals, and humans would likely suffer from the onslaught of insects formerly checked by cold winters. Low-rain summers are not good for fall foliage or maple syrup, nor do warming winters help winter sports-signature parts of the state's economy. ${ }^{20}$ Detailed analyses of how climate changes will affect coastal infrastructure, marine resources, agriculture, winter recreation, forests, birds, and human health are given in several recent reports. ${ }^{21}$ The overall pace of change is expected to increase through the century, due to "positive feedbacks," by which warming begets more warming. ${ }^{22}$

\section{Policy Options}

What might be done to prevent or soften such changes? U.S. greenhouse gas emissions for many decades outpaced the world. Although China recently surpassed the United States as the highest-volume source, we stand out on a per-person basis. Per-person emissions of carbon dioxide equaled about nineteen metric tons in 2006, so one American had the carbon impact of about one and a half Europeans, four Chinese, or ten Brazilians. ${ }^{23}$ With such high levels of consumption, there exists much room for improvement. Better efficiency would bring long-term economic benefits from development and sale of new technologies, as well as lower costs from climate and sea level changes and less dependence on foreign oil. Serious U.S. efforts to reduce emissions would not only clean domestic skies but also strengthen our case for asking (or through technology exports, helping) other nations to reduce their emissions.

The New Hampshire Climate Action Plan, a 2009 report for the state Department of Environmental Services, identified ways in which New Hampshire could boost economic development while at the same time reducing greenhouse gas emissions. The report noted, "The most significant reductions in both emissions and costs will come from substantially increasing energy efficiency in all sectors of our economy, continuing to increase sources of renewable energy, and designing our communities to reduce our reliance on automobiles for transportation." ${ }^{24}$

Better energy efficiencies nationwide could be motivated by government mandates such as automobile and electrical appliance standards and subsidies for new technologies. Alternatively, they might be motivated through higher prices, the market mechanism preferred by some economists. ${ }^{25}$ For example, a "carbon tax" on fossil fuels would create market incentives for efficiency that would benefit both the environment and our balance of trade.

This brief began with a look at some results from recent polls of public opinion about climate change. Two years earlier, we had asked some other climate-related questions in a similar New Hampshire poll. One question mentioned a gas tax: 
In order to help reduce energy use in the United States and to help slow global warming, some people have proposed that the federal government increase the gas tax by 50 cents per gallon. Do you favor or oppose that proposal, or are you unsure?

The response was strongly negative: 75 percent opposed such a tax, and most of those opposed said they would be "very upset" if the tax occurred anyway. Thus, whatever its theoretical advantages, this policy option faces strong opposition and little public support at present.

New Hampshire citizens, like climate scientists, can see that their climate is changing. More than a century of temperature and other records support this perception. Citizens agree less than most scientists, however, about what is causing climate change. To many people, scientific explanations of the greenhouse effect seem less tangible than the signs of earlier spring. Scientists face challenges in communicating their research to broad audiences. Future Carsey Institute briefs will track public opinion on this issue over time and also look at how it varies from place to place.

\section{Endnotes}

1. Pollsters often ask about "global warming," but many scientists prefer to speak of "climate change" instead, because global warming is misunderstood by some non-scientists to imply steady warming all over the globe (giving rise to the objection, "But it's cold here today!"). The scientific research on climate change involves many things besides temperature, such as shifting precipitation; frequencies of storms, droughts, or other extreme events, and even regional cooling in some places while the global average moves up.

2. For a more detailed look at the Granite State Poll results, see Lawrence C. Hamilton, "Do scientists agree about climate change? Public perceptions from a New Hampshire survey," Issue Brief No. 22 (Durham, NH: Carsey Institute, University of New Hampshire, 2010).

3. Other evidence for northern New Englanders' heightened awareness of climate change in their region can be seen in results from a 2007 CERA survey: Lawrence C. Hamilton and Barry D. Keim, "Regional variation in perceptions about climate change," International Journal of Climatology 29 (15) (2009): 2348-2352.

4. More detailed studies of climate change in New England or the northeastern United States include the following: K. Hayhoe et al., "Past and future changes in climate and hydrological indicators in the U.S. Northeast," Climate Dynamics 28 (4) (2007): 381-401; T. G. Huntington et al., "Climate and hydrological changes in the northeastern United States: Recent trends and implications for forested and aquatic ecosystems," Canadian Journal of Forest ResearchRevue Canadienne de recherche Forestière 39 (2) (2009):
199-212; NECIA (Northeast Climate Impacts Assessment), Climate Change in the U.S. Northeast: A Report of the Northeast Climate Impacts Assessment (Cambridge, MA: Union of Concerned Scientists, 2006); _-_, Confronting Climate Change in the U.S. Northeast: Science, Impacts, and Solutions (Cambridge, MA: Union of Concerned Scientists, 2007); NERA (New England Regional Assessment Group), "Preparing for a Changing Climate: The Potential Consequences of Climate Variability and Change," New England Regional Overview, U.S. Global Change Research Program (Durham, NH: University of New Hampshire, 2001); Cameron P. Wake et al., eds., "Special Issue:

Assessment of Climate Change, Impacts, and Solutions in the Northeast United States," Mitigation and Adaptation Strategies for Global Change 13 (5-6) (2008), 419-660.

5. All of the climate data used in this report are freely available to the public. The NASA global temperature anomaly index, called GISTEMP, is published here: http:// data.giss.nasa.gov/gistemp/; United States Historical Climatology Network (USHCN) weather station data are available from their Web site: http://cdiac.ornl.gov/epubs/ ndp/ushcn/ushcn_map_interface.html.

6. For panoramic views of the First Connecticut Lake site, which is far from urban heat, see http://gallery. surfacestations.org/main.php?g2_itemId=4622.

7. Smooth curves shown in Figures 2-7 were calculated by a statistical method called lowess regression, with bandwidths set at 30 to 60 percent of the data (narrower bandwidths were used with longer records). For a practical introduction to lowess smoothing, see Lawrence C. Hamilton, Statistics with Stata, updated for version 10 (Belmont, CA: Brooks/ Cole, 2009), 233-236.

8. The mid-century cooling seen in New Hampshire and global data has been a subject of detailed research. In the years during and after World War II, airborne pollutants measurably reduced the amount of sunlight reaching the earth's surface, particularly in northern mid-latitudes. This "dimming" effect temporarily offset the warming influence of carbon dioxide, which was steadily increasing. After the 1970s, reductions in air pollution over Europe and North America let more sunlight through, carbon dioxide continued to build up, and global temperatures began rising again. For an example, see M. Wild, A. Ohmura, and K. Makowski, "Impact of global dimming and brightening on global warming," Geophysical Research Letters (2007): doi:10.1029/2006GL028031.

9. Northern and southern New Hampshire winter temperatures were estimated for Figure 3 by averaging the USHCN stations within each region, as suggested (in preference to possibly biased U.S. Climate Division 
summaries) by Barry D. Keim, et al., "Are there spurious temperature trends in the United States Climate Division database?" Geophysical Research Letters 30 (7) (2003): 1404-1408. For a more detailed analysis of northeastern winter climate trends, see E. A. Burakowski et al., "Trends in Wintertime Climate in the Northeast United States, 1965-2005," Journal of Geophysical Research. 113 (2008): D20114, doi:10.1029/2008JD009870.

10. T. G. Huntington et al., "Changes in the proportion of precipitation occurring as snow in New England (19492000)," Journal of Climate 17 (2004): 2626-2636.

11. Ice-out dates are defined by local observation and custom but have been recorded for more than a century. For example, according to www.winnipesaukee.com, "Ice-Out on Lake Winnipesaukee occurs when the ice that has covered the Lake since late December or early January melts enough to allow the M/S Mount Washington cruise ship to navigate between Alton Bay, Center Harbor, Weirs Beach, Meredith and Wolfeboro." For more information about Lake Winnipesaukee, see http:// www.winnipesaukee.com/index.php?pageid=iceout; For the ice-out on Lake Sunapee, see http://www.town.sunapee.nh.us/ Pages/SunapeeNH_Clerk/ice.

12. For a more comprehensive study of ice-out dates across New England, see G. A. Hodgkins, I. C. James III, and T. G. Huntington, "Historical changes in lake ice-out dates as indicators of climate change in New England, 1850-2000," International Journal of Climatology 22 (2002): 1819-1827.

13. New Hampshire Department of Environmental Services, "Sea level rise," New Hampshire Department of Environmental Services. http://des.nh.gov/organization/ divisions/water/wmb/coastal/restoration/projects/sea_level. htm (accessed May 31, 2010); L. G. Ward and J. R. Adams, A Preliminary Assessment of Tidal Flooding Along the New Hampshire Coast: Past, Present, and Future, Final report submitted to the New Hampshire Office of Emergency Management and the Office of State Planning, 2001, http:// des.nh.gov/organization/divisions/water/wmb/coastal/ restoration/projects/documents/sea_level_rise_report.pdf.

14. Portland values graphed are RLR (revised local reference) data minus 7,000, from Proudman Oceanographic Library, "Permanent Service for Mean Sea Level," Proudman Oceanographic Library, http://www.pol.ac.uk/psmsl/datainfo/ (accessed July 21, 2010); For global sea level, our source is J. A. Church and N. J. White, "A 20th century acceleration in global sea-level rise," Geophysical Research Letters 33 (2006): doi:10.1029/2005GL024826; For an update and more about global sea level index, see http://www.psmsl.org/products/ reconstructions/church.php; Purely satellite-based data showing sea level rise since 1992 is available from the University of Colorado at http://sealevel.colorado.edu/results.php.
15. M. Vermeer and S. Rahmstorf, "Global sea level linked to global temperature," Proceedings of the National Academy of Sciences, http://www.pnas.org/content/106/51/21527.full.

16. Intergovernmental Panel on Climate Change, "Climate Change 2007-The Physical Science Basis," Contribution of Working Group I to the Fourth Assessment Report of the Intergovernmental Panel on Climate Change (Cambridge: Cambridge University Press, 2007).

\section{NECIA, Climate Change in the U.S. Northeast, 2006.}

18. K. Hayhoe et al., "Past and future changes in climate," 2007; NECIA, Climate Change in the U.S. Northeast, 2006.

19. NERA, "Preparing for a Changing Climate," 2001.

20. Lawrence C. Hamilton et al., "Warming winters and New Hampshire's lost ski areas: An integrated case study," International Journal of Sociology and Social Policy 23 (10) (2003): 52-73; Lawrence C. Hamilton, B. C. Brown, and Barry D. Keim, "Ski areas, weather and climate: Time series models for New England case studies," International Journal of Climatology 27 (2007): 2113-2124; T. G. Huntington et al., "Climate and hydrological changes," 2009.

21. T. G. Huntington et al., "Climate and hydrological changes," 2009; NECIA, Climate Change in the U.S. Northeast, 2006; Cameron P. Wake et al., eds., "Special Issue," 2008.

22. For example, warming sea and air temperatures have dramatically reduced summer ice cover on the Arctic Ocean. White ice reflects sunlight and insulates the ocean, whereas dark water absorbs heat and warms up. Thus, reduction of Arctic summer ice is changing the heat balance of the planet, which in turn affects winds, currents, and weather to the south.

23. United Nations, "Carbon dioxide emissions $\left(\mathrm{CO}_{2}\right)$, metric tons of $\mathrm{CO}_{2}$ per capita (CDIAC)," United Nations Statistics Division, Department of Economic and Social Affairs, http://mdgs.un.org/unsd/mdg/SeriesDetail. aspx?srid=751\&crid $=$.

24. New Hampshire Climate Change Policy Task Force, The New Hampshire Climate Action Plan (Concord, NH: New Hampshire Department of Environmental Services, 2009),

http://des.nh.gov/organization/divisions/air/tsb/tps/climate/ action_plan/documents/nhcap_final.pdf.

25. For example, M. Chinn, "Getting serious about the twin deficits" (New York: Council on Foreign Relations, 2005), http://www.cfr.org/content/publications/attachments/Twin DeficitsTF.pdf. 


\section{About the Authors}

Lawrence C. Hamilton is a professor of sociology at the University of New Hampshire and a senior fellow at the Carsey Institute (lawrence.hamilton@unh.edu).

Barry D. Keim is a professor of geography at Louisiana State University and serves as the Louisiana State Climatologist. From 1994 to 2002, he was New Hampshire's state climatologist (keim@lsu.edu).

Cameron P. Wake is a research associate professor with the Institute for the Study of Earth, Oceans, and Space at the University of New Hampshire (cameron.wake@unh.edu).

\section{ACKNOWLEDGMENTS}

The authors are grateful to Dr. Mary Stampone, New Hampshire State Climatologist, and to Dr. Nicholas Cox, geographical statistician, for their suggestions on an earlier draft.

\section{UNIVERSITY OFFICE OF \\ SUSTAINABILITY}

Since 1997, the University Office of Sustainability-the oldest endowed sustainability program in higher education in the United States-has been transforming UNH into a sustainable learning community across curriculum, operations, research and engagement, and initiatives in biodiversity, climate, food, and culture.

www.sustainableunh.unh.edu

\section{CARSEY}

\section{Building knowledge for families and communities}

The Carsey Institute conducts policy research on vulnerable children, youth, and families and on sustainable community development. We give policy makers and practitioners timely, independent resources to effect change in their communities.

This work was supported by the Carsey Institute endowment and the University Office of Sustainability.

Huddleston Hall

73 Main Street

Durham, NH 03824

(603) 862-2821

www.carseyinstitute.unh.edu 